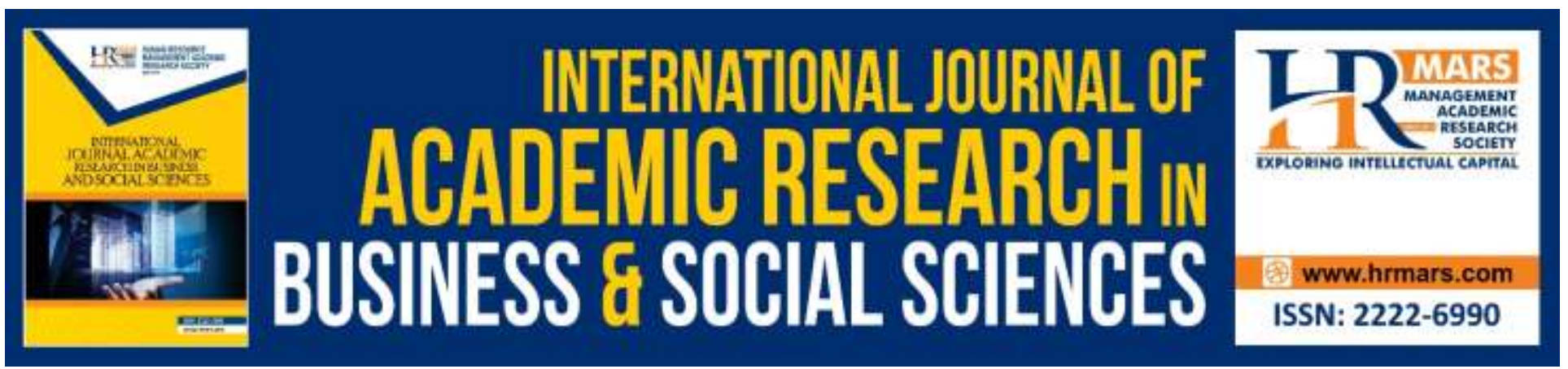

\title{
Comparative Study of Tax Services in ASEAN Countries
}

\author{
Deden Tarmidi, Nurlis, Erfan Erfiansyah, Rustandi
}

To Link this Article: http://dx.doi.org/10.6007/IJARBSS/v9-i7/6140

DOI: $10.6007 /$ IJARBSS/v9-i7/6140

Received: 23 May 2019, Revised: 12 June 2019, Accepted: 03 July 2019

Published Online: 26 July 2019

In-Text Citation: (Tarmidi, Nurlis, Erfiansyah, \& Rustandi, 2019)

To Cite this Article: Tarmidi, D., Nurlis, Erfiansyah, E., \& Rustandi. (2019). Comparative Study of Tax Services in ASEAN Countries. International Journal of Academic Research in Business and Social Sciences, 9(7), 484-494.

\section{Copyright: (c) 2019 The Author(s)}

Published by Human Resource Management Academic Research Society (www.hrmars.com)

This article is published under the Creative Commons Attribution (CC BY 4.0) license. Anyone may reproduce, distribute, translate and create derivative works of this article (for both commercial and non-commercial purposes), subject to full attribution to the original publication and authors. The full terms of this license may be seen

at: $\underline{\text { http://creativecommons.org/licences/by/4.0/legalcode }}$

Vol. 9, No. 7, 2019, Pg. 484 - 494

http://hrmars.com/index.php/pages/detail/IJARBSS

JOURNAL HOMEPAGE

Full Terms \& Conditions of access and use can be found at http://hrmars.com/index.php/pages/detail/publication-ethics 


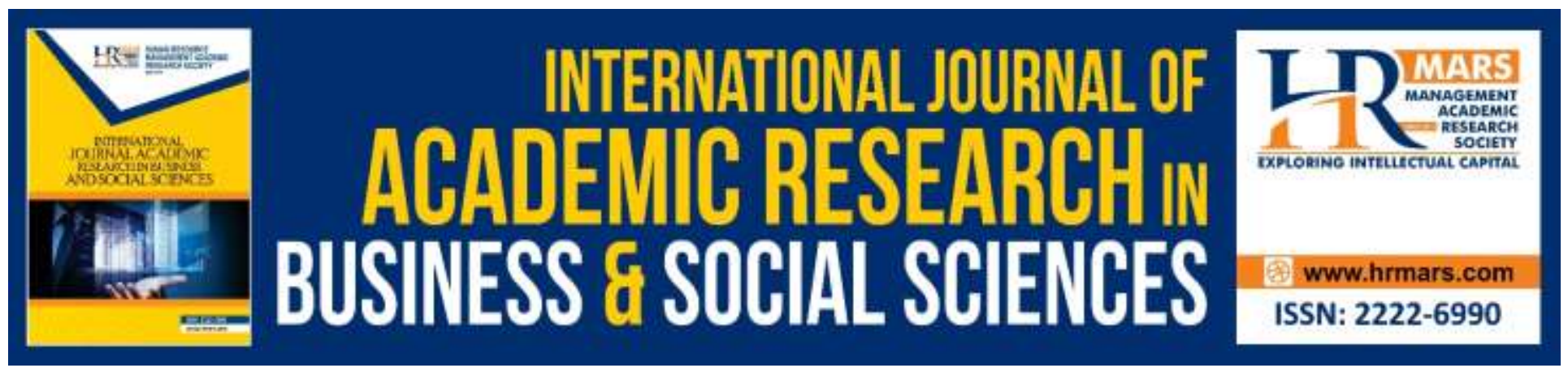

\title{
Comparative Study of Tax Services in ASEAN Countries
}

\author{
Deden Tarmidi, Nurlis \\ Faculty of Economic and Business, Universitas Mercu Buana, Jakarta, Indonesia \\ E-mail: deden.tarmidi@mercubuana.ac.id \\ Erfan Erfiansyah, Rustandi \\ Department of Accounting, Sekolah Tinggi Ilmu Ekonomi Muhammadiyah Bandung, Indonesia \\ E-mail:erfan@stiemb.ac.id
}

\begin{abstract}
This is a qualitative study analyzing tax services in ASEAN countries. As is known that for developing countries including some ASEAN countries, taxes are still a source of state income. So the state government issues special rules on taxation in regulating citizens' tax rights and obligations, including several rules regarding tax services. Some studies concluded that state revenues from taxes depend on the level of taxpayer compliance, and taxpayer compliance is more or less influenced by tax services that taxpayers can use to fulfill their tax rights and obligations.

Association of Southeast Asian Nations (ASEAN) was established in 1967 with 5 member countries at the beginning, until now the number of members reaches 10 countries. Although often called a cognate country, taxation policy is the authority of each State Government. So that the tax policy in one country is not certain the same as the other countries, including the tax services provided.

This study found that majority of ASEAN countries use self-assessment system for tax procedure except Singapore. Tax services including tax identity registration, tax payment an tax reporting in each country have used technology in majority ASEAN countries like Indonesia, Malaysia, Singapore, Thailand, Philippines, Brunei Darussalam, and Myanmar, while Cambodia only in tax identity number registration and tax payment services. As the new member of ASEAN, Vietnam and Lao PDR still manual in tax services for tax payer in each country like tax identity number registration, tax payment and tax reporting.
\end{abstract}

Keywords: Tax Services, ASEAN Countries

\section{Introduction}

Tax revenue has an important role for the development of a country, especially for developing countries including some ASEAN countries. Then each Government in ASEAN Countries takes certain policies such as tax policies so that the target of state revenue is achieved and the wheels of 
government run smoothly including the development of the state that has been declared by each country's leaders. In accordance with the policy, not a few types of taxes are required in each country as well as the applicable tax rate, sometimes even the applicable tax rates in the country undergo changes either down or up according to their respective policies and targets.

With the many types of taxes imposed in a country, there are more tax provisions as a guide to their implementation, this requires taxpayers to carry out their tax obligations extra. Conversely, the more types and tax rates required must be accompanied by policies in taxation services so as to help taxpayers in implementing their tax rights and obligations.

State revenues, especially those originating from taxes, are very closely related to the level of taxpayer compliance, the higher the level of taxpayer compliance, the higher the state tax revenue (Boll, 2013). While many factors influence taxpayer compliance, one of which is tax services. Some studies have found that the better the level of taxation services, the taxpayer will be more comfortable in carrying out their taxation rights and obligations so that they become obedient. So the government in each country continues to improve tax services so that the level of tax compliance is increasing (Eichfelder \& Kegels, 2014; Asatryan \& Peichi, 2016; Asrinanda, 2018).

Figure 1. Economic Growth in ASEAN Countries

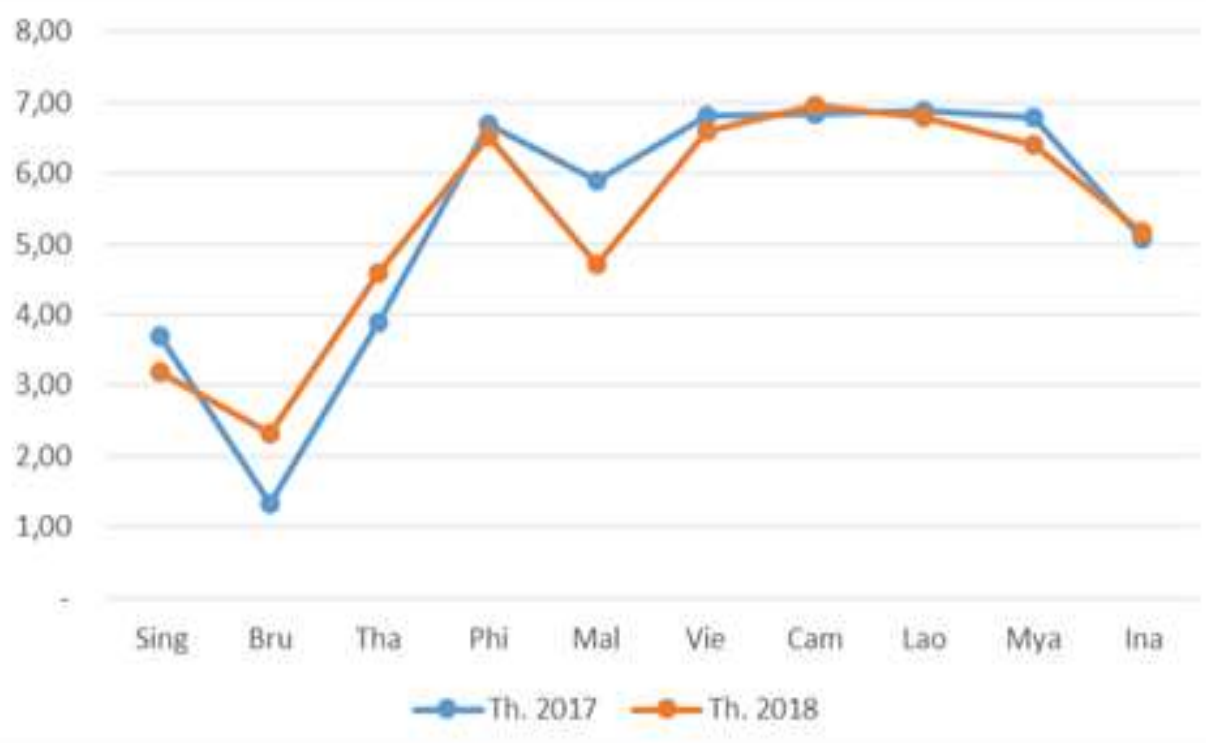

Resources by moneysmart.com

The development of ASEAN member countries so far has not been evenly distributed, both economic growth as listed in figure 1 is included in the acceptance and development of each of its members. Even though geographically, ASEAN member countries have natural resources and territories that are not much different.

The results of this study are expected to help businessman in considering investment or business between countries, especially in ASEAN member countries, this is because taxes are a burden for businesses and the tax burden has a relationship with tax services in a country and investor reacts to tax compliance of entity (Tarmidi, 2019). In addition, the results of this study are expected to be input 
INTERNATIONAL JOURNAL OF ACADEMIC RESEARCH IN BUSINESS AND SOCIAL SCIENCES

Vol. 9, No. 7, July, 2019, E-ISSN: 2222-6990 @ 2019 HRMARS

for the Government as a regulator in a country to consider taxation policies that will be taken so that economic development in the country develops well.

\section{Literature Review}

\section{Theoretical Framework}

\section{Public Service Management Theory}

In the early 1980s, the idea of businesslike emerged which led to a stream of renewal in public administration in the United States with a marked New Public Management (NPM) oriented to public administration reform with the main goal of improving public sector performance. Public administration is expected to act in a marketlike manner. One important aspect in NPM is to make public administration a customer driven government, meeting the needs of the customer, not the bureacracy (Osborne \& Gaebler, 1992) where the position of the people served by public administration is equated with customers to whom the government should be responsible (Rosenbloom \& Kravchuk, 2005).

NPM is essentially a public administration reform that requires the application of marketing principles in business administration to public administration. NPM has three main characteristics, namely the pursuit of achieving efficiency, using economic models in administration and politics, and applying the concept of competition to achieve customer satisfaction, market incentives and deregulation (Savas, 2000). In other words, NPM specifically means 3E, namely economy, efficiency and effectiveness (Tonge, 1993). Economy is a measure of how well the government gets its sources. Efficiency is a measure of how well the government uses and uses its resources to carry out public service activities. And effectiveness is a measure of the extent to which the government has achieved and fulfilled its main objectives.

\section{ASEAN}

So, The Association of the South East Asian Nation or ASEAN was established on August 5, 1967 in Bangkok Thailand by 5 (five) countries in Southeast Asia namely Indonesia, Malaysia, Singapore, Philippines and Thailand. At present ASEAN member countries are increasing Brunei Darussalam, Vietnam, Laos, Myanmar and Cambodia.

The establishment of ASEAN is based on the strong desire of its founders, namely to create a peaceful, safe, stable and prosperous region in Southeast Asia. This desire arose because in the 1960s the Southeast Asian region was faced with a situation prone to conflict both ideological conflicts of major countries and conflicts between countries in the Southeast Asia region which could disrupt regional stability and hamper development if it continued to be silenced.

The aim of the establishment of the ASEAN Community is to further strengthen ASEAN integration in facing the development of the international political constellation. ASEAN is fully aware that ASEAN needs to adjust its perspective so that it can be more open in facing internal and external problems. ASEAN countries realize the need to increase solidarity, cohesiveness and effectiveness of cooperation. Collaborative activities in ASEAN no longer only focus on economic cooperation but also must be supported by other cooperation in the field of security and socio-culture. 
Even so, the fact is that the development of each ASEAN country is not evenly distributed so it needs to be analyzed for its causes and its relationship to the factors that drive the country's revenues, especially in taxation in their respective countries.

\section{Tax Services}

As explained that tax is an obligation given by the Government of a country and is coercive to the community without direct reciprocity according to the terms and conditions that apply. So the Government should provide convenience in the form of services so that taxpayers carry out their tax obligations easily. According to Wallschutzky (1993), providing good service to taxpayers will lead to compliance. Glaser and Hildreth (1999) as quoted by Kelly (2005) also reveal that there is empirical evidence that residents are willing to pay high taxes because of services that can be trusted and carried out properly. Taxpayer compliance with its tax obligations will increase state revenues and in turn increase the size of the tax ratio.

As public service management theory explains that good service is a service that has the quality needed by the community, as well as tax services.

Furthermore, Esman (1991) as quoted by Turner and Hulme states, that in providing services to taxpayers, the participation of taxpayers is itself an important dimension in the administration of public services. In that, the taxpayer's reaction as one of the important dimensions in measuring service quality (Mohrman, 2006). Tax services are services provided by tax authorities to taxpayers based on tax laws, which if implemented incorrectly will result in sanctions for both taxpayers and the tax authorities themselves.

Some previous studies found that the taxpayer's perception of tax services in one country had an effect on the willingness of the taxpayer to comply. Murti et al. (2014), Jotopurnomo \& Mangoting (2013), Savitry \& Musfialdy (2016), Nurlis \& Kamil (2015), Syahril (2013) in their study found that taxpayers in Indonesia are interested in being more obedient when they feel good tax services.

\section{Conceptual Framework}

This research is a qualitative descriptive study, so it will be explained how the level and type of tax services in each ASEAN country. Although ASEAN countries are neighbors and have similarities, past history has an important influence on current tax policies in each country. Cooperation between ASEAN countries both in the economic field and exchange of tax information does not make the tax provisions in each ASEAN country the same. In addition, this study will also classify the same and different levels of taxation services in ASEAN countries.

\section{Methodology}

\section{Population and Sample}

The population of this study are ASEAN member countries, with the unit of analysis being the country, the sample of this study included in the saturated sample where all populations with 10 (ten) countries will be analyzed on the same topic, namely tax services in their respective countries. 


\section{Operational Variable}

In this qualitative descriptive study, the variable or topic studied is tax services, namely services provided by the Government in a country as a regulator that can be used by taxpayers in carrying out their tax rights and obligations. The type of tax service in a country will be different from other countries, as well as with ASEAN member countries. But broadly speaking, some tax services (and not limited to) are the regulation of tax services, tax registration services, tax counting services, tax payment services, and tax reporting services.

\section{Collection and Analisys Data Method}

In this study, data was obtained by means of literature and literature review, namely collecting data from existing public information, in this study data and information were obtained from scientific papers, websites of each country and other general publications related to the topic of this research. The data obtained in this study were analyzed descriptively then carried out a descriptive comparative analysis.

\section{Result \& Discussion} Indonesia

Indonesia uses self assessment on its taxation system, although for the Building and Land Tax there is still an official assessment. The increase in tax services in Indonesia is quite well developed. The launch of djponline to help taxpayers register tax identity number, make ebilling numbers for tax payments and also efilling for tax reporting has increased the level of tax compliance for both individual and corporate taxpayers. Since the electronic system disbursement in 2008, the level of compliance with tax reporting in Indonesia has continued to increase. The tax service increase was accompanied by an increase in the number of tax revenues from year to year, namely an increase of $30.48 \%$ from 2015 to 2018 , even though it still had not reached the target that was also increased by the Government. With the increase in tax revenues over the past 4 years, Indonesia's economic growth also increased from $4.88 \%$ in 2015 to $5.17 \%$ in 2018.

\section{Malaysia}

With the self assessment system, Malaysian taxpayers have the authority to calculate, pay and report their own taxes. By using MyKad as a single card identity, every Malaysian citizen is automatically registered as a Malaysian taxpayer when the subject and object are fulfilled. With the tax deposit service electronically through the egov.my website, the Malaysian Authority provides services that make it easier for taxpayers to pay their taxes on-line as well as tax reporting that can be done through a website provided online. As with the public service management theory, tax services provided by the Government for Taxpayers have an impact on the tax revenue itself from an increase of $0.75 \%$ in 2015 to $6.4 \%$ in 2017 . The increase in tax revenues was followed by Malaysian economic growth of $5.4 \%$ in the first quarter of 2018.

\section{Singapore}

Unlike most other ASEAN countries, Singapore uses official assessment in its taxation system. Each Taxpayer, both Individuals and Companies connected to Tax Payer, is permitted to temporarily 
calculate the tax payable even though it will still be recalculated by IRAS as a Tax Authorities in Singapore. As a country that has developed rapidly among its neighbors in ASEAN, Tax Authorities in Singapore provide electronic services in depositing and reporting taxes through the website provided, namely iras.gov.sg. Taxation services in Singapore have an impact on increasing tax revenues from $4.3 \%$ growth in 2014/2015 to 6.8\% in 2017/2018 tax year along with Singapore's economic growth which increased from $2 \%$ growth in 2015 to growth $2.2 \%$ at the end of 2018.

\section{Thailand}

Like other countries in ASEAN, Thailand also applies a self-assessment system in its taxation procedures. Taxpayers can register themselves to become taxpayers through electronic services provided. Individual taxpayers and companies that have been registered are given the authority to calculate their own taxes and can then pay and report using electronic services provided by the Tax Authorities through the rd.go.th website. For the tax services provided by the Thai Government, the OECD noted that tax revenues in Thailand are increasing every year with an increase in average from 2014 to 2017 of $1.912 \%$.

\section{Philippines}

The Government of the Philippines provides the best services for taxpayers there to register as taxpayers, pay taxes and report taxes on the same website, namely bir.gov.ph even though taxpayers are also given the authority to report taxes manually to RDO officers (Revenue District Officer). With a self assessment system, taxpayers are given the authority to calculate their own taxes. The OECD noted that Philippines tax revenues increased rapidly every year, with an average increase in tax revenues between 2014 and 2017 of $10.40 \%$.

\section{Brunei Darussalam}

As a country that is classified as rich, taxes in Brunei Darussalam are only imposed on business companies, while individuals do not. Even so, electronic-based tax services can be used by taxpayers to register themselves, deposit taxes and also report taxes on the SARS.gov.bv website.

\section{Cambodia}

Using the Self Assessment System, the Government of Cambodia provides tax services well so that people can register as taxpayers electronically and also make payments through the website tax.gov.kh while tax reporting is still manual. Worldbank reported that tax revenues compared to GDP in Cambodia experienced a fairly good increase with an average increase of $7.24 \%$ in 2014 to 2017.

\section{Lao PDR}

As a new member of ASEAN, Lao PDR growth is considered to be sufficiently developed and the Lao PDR Government is starting to improve in tax services. With the self assessment system, tax services in Lao PDR are still manually starting from registration of tax Identity Number, tax calculation to tax reporting. 
INTERNATIONAL JOURNAL OF ACADEMIC RESEARCH IN BUSINESS AND SOCIAL SCIENCES

Vol. 9, No. 7, July, 2019, E-ISSN: 2222-6990 @ 2019 HRMARS

\section{Viet Nam}

Vietnam is part of the new ASEAN member after 5 founding countries. With a self assessment system, tax services in Vietnam are still developing with a manual system on registration of tax identity number, tax payment and tax reporting services and self service on calculating tax payable as Lao PDR.

\section{Myanmar}

As a country that has been highlighted by the media in recent times, Myanmar has begun to struggle to become a developing country and tax revenues are considered as a way to advance the country's economy. For this purpose, the Government provides good tax services such as electronic services on the registration of tax identity number, tax deposits and tax reporting. With the self assessment system, the calculation of tax payable is still given authority to the taxpayer. The growth of tax revenues compared to Myanmar's GDP has increased rapidly, Worldbank reported that tax revenues compared to GDP in Myanmar on average experienced an increase in 2014 to 2017 amounting to $2.26 \%$.

\section{Comparative Study}

Judging from the taxation system used in the ASEAN countries, self assessment systems are generally used by the majority of ASEAN members except Singapore. From the differences in the system, there are several differences in the form of tax services on tax payers in each country. There are countries that still use manual procedures for tax identity number, tax payments and reporting even though the majority have used service procedures electronically with each special procedure. The use of technology in tax services and self-assessment systems is thought to be one of the causes of increased tax compliance (Asrinanda \& Diantimala, 2018) and tax revenues (Ballm 2013).

\section{Conclusion}

Tax Services in ASEAN Countries have been quite good, the use of technology in the tax service system both in the registration of tax id number, tax payment and tax reporting has helped taxpayers to carry out their tax obligations so that tax revenues in most ASEAN countries continue to increase and help develop their respective each countries. With the self assessment system adopted in most ASEAN countries, taxpayers are given the authority to calculate, payment and report their own taxes.

As explained the theory of public service management that the government provides services to the community with 3 characteristics, namely economy, efficiency and effectiveness, tax services in ASEAN countries are at a good stage. With the majority of ASEAN countries using technology in taxation services, the characteristics of the New Public Management already exist because the taxation services can minimize the resources they have, time and cost efficiency and effectiveness in the tax service process.

The results of this study make practical and theoretical contributions. Practically, the results of this study provide information in a description of taxation services in ASEAN countries. Leaders in ASEAN countries in particular as well as other countries in general can study the results of this research as input into the country's taxation policies with respect to the development goals in their respective countries. Theoretically, this study illustrates that the new theory of public management has been implemented by governments in most ASEAN countries. Public services in taxation have been 
INTERNATIONAL JOURNAL OF ACADEMIC RESEARCH IN BUSINESS AND SOCIAL SCIENCES

Vol. 9, No. 7, July, 2019, E-ISSN: 2222-6990 ¿ 2019 HRMARS

improved to help taxpayers fulfill their taxation rights and obligations, electronic tax services have been widely used with the aim of ease and efficiency.

\section{Implication and Limitation}

Some implication can be information for better applicated of tax services and some limitation in this study can be information for better future study:

1. ASEAN countries have advanced in providing tax services so that indirectly can support investment in the country, investors need not hesitate in investing and doing business in ASEAN countries.

2. The lack of information about tax services in each ASEAN country raises unbalanced information about tax services in each country. It is expected that each government can provide informative information so that it is more easily understood by the public.

\section{Acknowledgment}

This paper is the result of study on domestic cooperation between the faculty of economics and business Universitas Mercu Buana dan Sekolah Tinggi Ilmu Ekonomi Muhammadiyah Bandung. We would like to thank all those who have helped in this study, especially the research center team, the head of the program and the deans and the heads of each university.

\section{References}

Asatryan Z., \& Peichi A. (2016). Repsonses of firm to tax, administrative and accounting rules: evidence from Armneia. ZEW - Center of European Economic Research Discussion Paper No. 16-065 (2016). Downloaded at July 7, 2019 from https://papers.ssrn.com/sol3/papers.cfm?abstract_id=2850534

Asean.org. (2009). ASEAN Member States. Accessed at July 7, 2019 from https://asean.org/asean/asean-member-states/

Asrinanda, Y. D. (2018). The Effect of Tax Knowledge, Self Asessment System, and Tax Awarness on Taxpayer Compliance. International Journal of Academic Research in Business and Social Science, 8(10), 539-550. DOI: 10.6007/IJARBSS/v8-i10/4762

Bergman, B. \& Kelfsjo, B. (1994). Quality from Customer Needs to Customer Satisfaction. Lund (Sweden), Studentliterature.

Boll, K. (2013). Mapping tax compliance assemblages, distributed action and practices: a new way of doing tax research. Critical Perspective on Accounting, Vol. 25, issue 4-5, July 2014, pp. 293303. DOI: 10.1016/j.cpa.2013.03.002

Boby (2019). Ekonomi Indonesia Mentok di 5, 17 Persen, Gimana dengan Negara-Negara ASEAN ini?. Accessed at January 3, 2019 from https://www.moneysmart.id/ekonomi-negara-asiatenggara/

Eichfelder S., \& Kegels, C. (2014). Compliance costs caused by agency action? Empirical evidence and implications for tax compliance. Journal of Economic Psychology, Vol. 40, February 2014, pp. 200-219. DOI: 10.1016/j.joep.2012.08.012

Esman, M. J. (1991). Management Dimensions of Development: Perspective and Strategies, Connecticut: Kumarian Press 
INTERNATIONAL JOURNAL OF ACADEMIC RESEARCH IN BUSINESS AND SOCIAL SCIENCES

Glaser, M. A., \& Hildreth, W. B. (1999). Service Delivery Satisfaction and Willingness to Pay Taxes: Citizen Recognition of Local Government Performance. Public Productivity \& Management Review, Vol. 23 No. 1, pp. 48-67. DOI: 10.2307/3380792

Humas. (2019). Tertinggi Sejak 2014, BPS: Ekonomi Indonesia 2018 Tumbuh 5, 17 Persen. Accessed at July 7, 2019 from https://setkab.go.id/tertinggi-sejak-2014-bps-ekonomi-indonesia-2018tumbuh-517-persen/

Inland Revenue Authority of Singapore. (2018). Tax Statistics. Accessed at July 7, 2019 from https://www.iras.gov.sg/IRASHome/Publications/Statistics-and-Papers/Tax-Statistics/

Jotopurnomo, C. \& Mangoting, Y. (2013). Pengaruh Kesadaran Wajib Pajak, Kualitas Pelayanan Fiskus, Sanksi Perpajakan, Lingkungan Wajib Pajak Berada terhadap Wajib Pajak Orang Pribadi di Surabaya. Tax \& Accounting Review, Vol. 1(1), 49-54. Downloaded at July 7, 2019 from https://www.neliti.com/publications/157195/pengaruh-kesadaran-wajib-pajak-kualitaspelayanan-fiskus-sanksi-perpajakan-lingk

Katadata. (2018). Inilah Tarif dan Jumlah Pajak di Kawasan Asia Tenggara. Downloaded at January 9, 2018 from https://databoks.katadata.co.id/datapublish/2018/01/09/inilah-tarif-dan-jumlahpajak-di-kawasan-asia-tenggara

Kelly, J. M. (2005). The Dillemma of the Unstatisfied Customer in a Market Model of Public Administration. Public Administration Review, Washington: Jan/Feb 2005, Issue 1, 77-78. Downloaded at July 7, 2019 from https://www.jstor.org/stable/3542583

Kementrian Kewangan Malaysia . (2017). Anggaran Hasil Kerajaan Persekutuan 2018. Downloaded at July 7, 2019 from https://www.treasury.gov.my/pdf/percukaian/penerbitan/ buku_anggaran_hasil_kerajaan_persekutuan_2018.pdf

Mohrman, D. (2006). Cardiovascular Physiology, 6th Edition. Singapore: McGraw Hill Education

Murti, H. W., Sondakh, J. J, \& Sabijono, H. (2014). Pelayanan Fiskus dan Pengetahuan Perpajakan terhadap Kepatuhan Wajib Pajak Orang Pribadi di Kota Manado. Jurnal EMBA: Jurnal Riset Ekonomi, Manajemen, Bisnis dan Akuntansi, Vol. 2(3), 389-398. Downloaded at July 7, 2019 from https://ejournal.unsrat.ac.id/index.php/emba/article/view/5556

Nurlis, \& Kamil, I. (2015). The Effect of Taxpayer Awareness, Knowledge, Tax Penalties and Tax Authorities Services on the Tax Complience. Research Journal of Finance and Accounting, Vol. 6 (2), 104-111. Accessed at July 7, 2019 from https://www.iiste.org/Journals /index.php/RJFA/article/view/19180/19738

Osborne, D., \& Gaebler, T. (1992). Reinventing Government: How The Entrepreneur Spirit is Transforming The Public Service, terjemahan : Mewirausahakan Birokrasi

Mentransformasikan Semangat Wirausaha ke Dalam Sektor Publik. Alih Bahasa Abdul Rosyid dan Ramelan. Jakarta : Pustaka Binaman Pressindo.

Osborne, D., \& Plastrik, P. (1997). Banishing Bureaucracy, The Five Strategies for Reinventing Government, terjemahan: Memangkas Birokrasi: Lima Strategi Menuju Pemerintahan Wirausaha, Alih Bahasa: Abdul Rosyid dan Ramelan. Jakarta: Penerbit PPM.

Osborne, S. P., Radnor, Z., \& Nasi, G. (2012). A New Theory for Public Service Management? Toward a (Public) Service-Dominant Approach. American Review of Public Administration, 43 (2) 135158. DOI: $10.1177 / 0275074012466935$ 
INTERNATIONAL JOURNAL OF ACADEMIC RESEARCH IN BUSINESS AND SOCIAL SCIENCES

Vol. 9, No. 7, July, 2019, E-ISSN: 2222-6990 ¿ 2019 HRMARS

Rosenbloom, D. H., \& Kravchuk, R. S. (2005). Public Administration: Understanding Management, Politics, and Law in the Public Sector. Singapore: McGrawHill.

Saputra, P. A. (2019). Outlook Penerimaan Pajak Indonesia Tahun Anggaran 2019 Strategi dan Tantangannya. Downloaded at July 7, 2019 from\ http://iaiglobal.or.id/v03/files/file_publikasi/Materi\%20IAl_280119.pdf

Savas, E. (2000). Privatization and Public Private Partnership. London: Chantam House Publisher

Savitri, E., \& Musfialdy. (2016). The Effect of Taxpayer Awareness, Tax Socialization, Tax Penalties, Compliance Cost at Taxpayer Compliance With Service Quality as Mediating Variable. Procedia-Social and Behavioral Sciences, 219 (2016), 682-687. DOI:

10.1016/j.sbspro.2016.05.051

Tarmidi, D. (2019). Tax Compliance and Uncompliance Entity: A Comparative Study of Investor Reaction. International Journal of Academic Research in Accounting, Finance and Management Sciences, 9 (1): 105-110. DOI: 10.6007/IJARAFMS/v9-i1/5823

Tonge, R. (1993). Managing the New Public Service. Houndmills, Bastinstoke, London: The Macmillan Press Lt.

Wallschutzky, I. (1993). Minimizing Evasion and Avoidance?, in Sanford, Cedric (ed), Key Issues in Tax Reform. England: Fiscal Publication.

Zeithaml, V. A., Parasuraman, A., \& Leonard, L. B. (1990). Delivering quality service balancing customer perceptions and expectations. New York: The Free Press. 